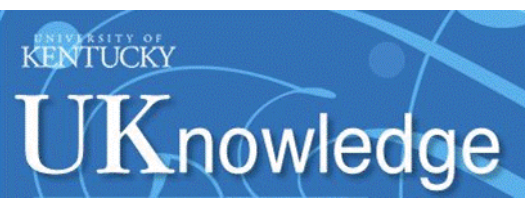

University of Kentucky

UKnowledge

$9-4-2021$

\title{
Competitive Rationales: Beneath the Surface of Competitive Behavior
}

\author{
Goce Andrevski \\ Queen's University, Canada \\ Danny Miller \\ HEC Montreal, Canada \\ Isabelle Le Breton-Miller \\ HEC Montreal, Canada \\ Walter Ferrier \\ University of Kentucky, wallyf@uky.edu
}

Follow this and additional works at: https://uknowledge.uky.edu/management_facpub

Part of the Management Sciences and Quantitative Methods Commons

Right click to open a feedback form in a new tab to let us know how this document benefits you.

\section{Repository Citation}

Andrevski, Goce; Miller, Danny; Le Breton-Miller, Isabelle; and Ferrier, Walter, "Competitive Rationales:

Beneath the Surface of Competitive Behavior" (2021). Management Faculty Publications. 7.

https://uknowledge.uky.edu/management_facpub/7

This Article is brought to you for free and open access by the Management at UKnowledge. It has been accepted for inclusion in Management Faculty Publications by an authorized administrator of UKnowledge. For more information, please contact UKnowledge@lsv.uky.edu. 
Competitive Rationales: Beneath the Surface of Competitive Behavior

\section{Digital Object Identifier (DOI)}

https://doi.org/10.1177/01492063211040555

\section{Notes/Citation Information}

Published in Journal of Management.

(c) The Author(s) 2021

This article is distributed under the terms of the Creative Commons Attribution 4.0 License (https://creativecommons.org/licenses/by/4.0/) which permits any use, reproduction and distribution of the work without further permission provided the original work is attributed as specified on the SAGE and Open Access pages (https://us.sagepub.com/en-us/nam/open-access-at-sage). 
Journal of Management

Vol. XX No. X, Month XXXX 1-32

DOI: $10.1177 / 01492063211040555$

(C) The Author(s) 2021

(c) (i)

Article reuse guidelines:

sagepub.com/journals-permissions

\title{
Competitive Rationales: Beneath the Surface of Competitive Behavior
}

\author{
Goce Andrevski (iD \\ Queen's University \\ Danny Miller \\ Isabelle Le Breton-Miller (D \\ HEC Montreal \\ Walter Ferrier \\ University of Kentucky
}

\begin{abstract}
Competitive dynamics research has focused on studying whether rivals are able and likely to carry out competitive actions, typically by examining indirect reasons such as characteristics of the actions themselves, the firms involved, or the competitive context. We explore why rivals initiate a specific competitive action at a particular time and situation. Drawing from the philosophy of action literature, we introduce the concept of competitive rationales to examine the primary reasons that cause tactical actions. Given the rapid exchanges characterizing tactical competitive dynamics, we conducted an inductive, multicase study to explore the reasons behind over 800 discrete tactical decisions carried out by 9 professional basketball coaches during 15 basketball games. To garner insight, we develop a conceptual framework revealing their types and scope. Even during intense head-to-head rivalry, most rationales were not rivalrous but were instead organizational-to optimize resource use, strategic consistency, and reputation-or social-to manage relationships. Moreover, the three main types of rationales varied in scope, extending beyond immediate competitive situations and rivals to address longer term, strategic outcomes, and assorted stakeholders. Thus, our analysis reveals these rationales to be complex and potentially difficult for rivals to decipher. It also recasts each component of the dominant awarenessmotivation-capability (AMC) model of rivalry, suggesting that awareness is challenged by
\end{abstract}

\footnotetext{
Acknowledgments: This study was supported by the Social Sciences and Humanities Research Council (SSHRC) of Canada and the Basketball Federation of Macedonia. We are grateful to Gavin Kilduff, Ann Langley, Tomi Nokelainen, Editor Tieying $\mathrm{Yu}$, and two anonymous reviewers for their most useful comments on earlier versions of this manuscript.

Corresponding author: Goce Andrevski, Queen's University, 242 Goodes Hall, Kingston, ON K7L3N6, Canada.

E-mail: goce.andrevski@queensu.ca
} 
subtle rationales, motivation drives not only action but also forbearance, and capability is both a requirement and product of action.

Keywords: competitive rationales; competitive intent; competitive dynamics; tactical actions; strategic forbearance; managerial cognition

\section{Introduction}

Competitive action is the central construct and a key distinguishing feature of competitive dynamics research (Chen \& Miller, 2012, 2015). Defined as "a specific and detectable competitive move, such as a price cut or a new product introduction initiated by a firm, to defend or improve its relative competitive position" (Smith, Grimm, Gannon, \& Chen, 1991: 61), competitive actions are essential components of competitive attacks and responses (Chen \& Miller, 1994), competitive aggressiveness (Andrevski \& Ferrier, 2019; Ferrier \& Lee, 2002), competitive complexity (Connelly, Tihanyi, Ketchen, Carnes, \& Ferrier, 2017), and inertia (Miller \& Chen, 1996).

Unfortunately, the primary reasons why managers carry out specific competitive actions and responses remain underexplored. Competitive dynamics research has examined various factors that drive competitive actions: superior capabilities (e.g., Andrevski, Brass, \& Ferrier, 2016; Carnes, Xu, Sirmon, \& Karadag, 2019; Gnyawali \& Madhavan, 2001; Ndofor, Sirmon, \& He, 2011; Smith et al., 1991), market centrality and multimarket contact (e.g., Chen \& Miller, 1994; Livengood \& Reger, 2010; McGrath, Chen, \& MacMillan, 1998; Yu \& Cannella, 2013), subjective perceptions of rivalry and tension (e.g., Chen, Su, \&Tsai, 2007; Kilduff, Elfenbein, \& Staw, 2010), and managerial cognitive dispositions (e.g., Hambrick, Cho, \& Chen, 1996; Nadkarni \& Barr, 2008; Nadkarni \& Chen, 2014). However, those factors are not the primary reasons for a specific action. They describe what enables, stimulates, and hinders the motivation to carry out any competitive action. For example, competitive tension or superior capability can tempt action but cannot explain why a firm initiates a specific action at a particular time or situation, nor what a firm is attempting to achieve with that action.

Drawing on the philosophy of action literature, we introduce the construct of competitive rationale in studying the primary reasons that directly cause a specific competitive action or inaction. We apply the causal theory of action to provide theoretical underpinnings of competitive rationales (Davis, 2013; Davidson, 1963; O’Connor, 2013). This theory “can explain a person's actions by citing the reasons for which (s)he did them" (Davis, 2013: 35). Primary reasons are an agent's own reasons for performing an action. They describe what an agent wants to achieve and why it carries out that particular action, which is a prerequisite for predicting competitive behavior, a central goal of competitive dynamics research (Chen \& Miller, 2012). In seeking these reasons or competitive rationales, we hope to reveal both their principal types and scope domains.

Most research has studied drivers of strategic rather than tactical actions, which, by comparison, require less time, expertise, and resources to develop and implement. Yet firms compete predominantly via tactical actions, often by middle-management - a reality evident in empirical studies of competitive aggressiveness, inertia, and simplicity (Ferrier, 2001; Ferrier 
\& Lee, 2002; Ferrier, Smith, \& Grimm, 1999; Miller \& Chen, 1994, 1996) and by work showing how tactics can overwhelm rivals and neutralize attacks (Andrevski \& Ferrier, 2019). Because tactical behavior embodies, implements, and adapts strategy (Chen \& Miller, 2015), it tends to reflect "strategic" purpose (Van den Steen, 2018).

Our study explores competitive rationales - primary reasons - that directly cause tactical actions. It asks: What types of rationales drive tactical actions, and what is their scope in competitive rivalry? Given the rapid exchanges characterizing tactical competitive dynamics (Chen \& MacMillan, 1992), we conducted an inductive, multicase study to examine the reasoning behind over 800 discrete tactical decisions carried out by 9 professional basketball coaches during 15 basketball games. We interviewed coaches and asked them to elaborate on their rationales for each considered action. The context enabled us to concentrate on tactical actions, as when a game is in progress, coaches have limited time and resources to execute. In addition, owing to its simplicity vis-à-vis business situations, our setting is an exacting one for discovering the strategic role of tactics. "Studying a case that is likely to display the lowest incidence or intensity of some feature in a population, we can assume that the rest of the population is above the level identified" (Gomm, Hammersley, \& Foster, 2000: 108). Indeed, compared to most midlevel tactical business managers, basketball coaches have less time, resources, or opportunity to devise and execute tactics during a game. Thus, if tactical rationales are shown to be nuanced and diverse where tactics are executed with limited resources in seconds, they are likely to be even more so in business contexts (Grimm \& Smith, 1997).

Our conceptual framework for competitive rationales consists of two dimensions: rationale type and rationale scope. First, competitive rationales are not solely rivalrous but more often organizational and social. In fact, rivalrous rationales - those primarily oriented to outmaneuver competitors - represented just one third of the total. Surprisingly, even in intense head-to-head tactical competition, most rationales were organizational, intended to orchestrate resources, learn through experience, and improve strategic coherence and execution. Other types of rationales were social, focusing on managing relationships with stakeholders. Second, the scope of rationales varies across three distinct domains: the immediate situation with rivals, those relating to longer term outcomes, and those involving stakeholders other than rivals. We found that $67 \%$ of rationales were intended not only to develop, preserve, and optimize resources but also to achieve temporally extended objectives, adjust strategy, and manage stakeholder relationships.

Our findings suggest important modifications to the dominant AMC model of competitive dynamics. We find that the complexity and inscrutability of rationales conceal rival intentions, thereby challenging and recasting the awareness component of the AMC model. Understanding the type and scope of each rationale can help interpret actions. Regarding motivation, we find rationales to underlie the motivation not only to act but also to strategically forbear, surfacing motivations pertaining to more distal time intervals, parties other than current rivals, and strategies more than unitary moves. Finally, whereas previous research has capability driving actions, we found the opposite: Actions often aim to build capabilities by dynamically managing resources for future advantage. In short, tactical actions constitute subtle and multifaceted vehicles for achieving long-term, strategic objectives, thereby broadening current understandings.

In the pages that follow, we provide a theoretical foundation of the concept of competitive rationales before describing our guiding research questions, methodology, conceptual 


\section{Table 1}

Distinctive Aspects of Our Study and Principal Findings

\begin{tabular}{|c|c|c|}
\hline Distinctive Aspects & Typical CD Studies & Our Study of Rationales \\
\hline \multirow[t]{2}{*}{ Research focus } & Strategic decisions & Tactical decisions \\
\hline & $\begin{array}{l}\text { Indirect reasons and goals that } \\
\text { incentivize managers to act }\end{array}$ & $\begin{array}{l}\text { Immediate reasons about "why" a coach } \\
\text { initiates a specific action in a given time } \\
\text { and situation }\end{array}$ \\
\hline \multirow[t]{3}{*}{ Research method } & $\begin{array}{l}\text { Rationales inferred from observable } \\
\text { attributes }\end{array}$ & $\begin{array}{l}\text { Rationales directly accessed from coaches' } \\
\text { statements }\end{array}$ \\
\hline & Quantitative analysis & Qualitative analysis \\
\hline & Deduction & Induction \\
\hline Principal Findings & Typical CD Studies & Our Study of Rationales \\
\hline Reasons for action & $\begin{array}{l}\text { Indirect reasons that can affect any } \\
\text { action }\end{array}$ & $\begin{array}{l}\text { Primary reasons that directly cause } a \text { specific } \\
\text { action or inaction }\end{array}$ \\
\hline Types of rationales & Rivalrous rationales & $\begin{array}{l}\text { Rivalrous, organizational, and social } \\
\text { rationales }\end{array}$ \\
\hline Scope of rationales & $\begin{array}{l}\text { A single target domain: immediate rival, } \\
\text { actions, outcomes }\end{array}$ & $\begin{array}{l}\text { Three target domains: immediate situation, } \\
\text { long-term strategic outcomes, and other } \\
\text { implicated parties beyond a direct rival }\end{array}$ \\
\hline $\begin{array}{l}\text { Nature of } \\
\text { rationales }\end{array}$ & $\begin{array}{l}\text { Simple, parsimonious indirect factors } \\
\text { that stimulate strategic actions (e.g., } \\
\text { attack irreversibility; firm size, market } \\
\text { commonality, cognitive dispositions) }\end{array}$ & $\begin{array}{l}\text { Rich, nuanced and diverse, } 43 \text { primary } \\
\text { rationales (e.g., setting a trap, deceiving a } \\
\text { rival, exploiting rival weakness, preserving } \\
\text { rival dignity) }\end{array}$ \\
\hline $\begin{array}{l}\text { Orientation toward } \\
\text { action }\end{array}$ & $\begin{array}{l}\text { Empirical examination of active } \\
\text { behavior }\end{array}$ & $\begin{array}{l}\text { Empirical examination of both active and } \\
\text { passive purposeful behavior (i.e., actions } \\
\text { and forbearances) }\end{array}$ \\
\hline $\begin{array}{l}\text { Strategic } \\
\text { importance of } \\
\text { tactics }\end{array}$ & Tactics are not strategic & $\begin{array}{l}\text { Tactics can have long-term, broader, strategic } \\
\text { roles in building resource advantages and } \\
\text { maintaining strategic consistency }\end{array}$ \\
\hline
\end{tabular}

framework and findings, and the implications of our study for the AMC model and more generally. Table 1 highlights the distinctive orientation and findings of our study and compares it to previous work in competitive dynamics.

\section{Conceptual Development}

\section{Prior Work and Orientations}

Scholars of competitive dynamics have long sought to provide insights into firm rivalry by probing "the motivations and cognitions of actors who initiate and respond to competitive actions" (Chen \& Miller, 2012). Most research has concentrated on conceptual models of how managers identify and process data about rival firms, with little information coming from the managers themselves. For example, early work applied a simple expectancyvalence framework to explain how the value of a reward and the probability of its attainment triggered competitive attacks and responses (Chen \& Miller, 1994). Building on this work, some studies adopted the influential AMC model to explain behavior based on a firm's awareness of a rival attack and its motivation and capability to respond (Chen, 1996). 
Critically, inferences associated with these qualities were drawn from properties of the actions themselves, such as complexity, irreversibility, timing, or strategic importance (Chen \& MacMillan, 1992; MacMillan, McCaffery, \& van Wijk, 1985; Smith et al., 1991).

Some studies found that managerial awareness was heightened when other firms were reputed market leaders or predators or when they possessed similar resources and markets in common (Chen, 1996; Gimeno \& Woo, 1996; MacMillan et al., 1985; Smith, Grimm, \& Gannon, 1992). It was also influenced by top team heterogeneity and information-processing capacity (Hambrick et al., 1996; Marcel, Barr, \& Duhaime, 2010; Nadkarni \& Chen, 2014; Smith et al., 1991). By contrast, action complexity and the use of vague language were argued to obscure intent, compromising awareness (Gao, Yu, \& Cannella, 2016; Guo, Yu, \& Gimeno, 2017). Interpretation was also shaped by managerial cognitive frameworks (Marcel et al., 2010) and temporal dispositions (Chen \& Nadkarni, 2017; Nadkarni, Chen, \& Chen, 2016).

Core contextual drivers of the motivation to engage included market centrality and identity domains (Chen \& Miller, 1994; Livengood \& Reger, 2010), prior interactions, tension between rivals, network embeddedness, resource similarity, and multimarket contact (Chen et al., 2007; Gnyawali \& Madhavan, 2001; Kilduff et al., 2010; Young, Smith, \& Grimm, 1996; Yu \& Cannella, 2013).

Finally, a frequently cited stimulus for action was superior capability. A firm was found to act or respond when it had superior technological resources (Ndofor et al., 2011), network positions and alliances (Andrevski et al., 2016; Gnyawali \& Madhavan, 2001), informationprocessing capacity (Chi, Ravichandran, \& Andrevski, 2010; Smith et al., 1991), slack resources (Carnes et al., 2019), and scale (Chen \& Hambrick, 1995).

Although this research provides important insights into the processes of attending and reacting to competitive information, our understanding of the reasons for managers' competitive actions remains limited. Most research has tended to infer the reasons behind actions indirectly from the attributes or features of managers, firms, markets, and actions. What remain underexplored are managers' own rationales that explain why actions are initiated at a specific time and in a specific context. In this study, we introduce the concept of competitive rationale and, based on our findings, develop a framework capturing and classifying key rationales that drive tactical actions.

\section{The Concept of Competitive Rationale}

We leverage the causal theory of action to provide a theoretical foundation for competitive rationales (Davis, 2013; Davidson, 1963; O'Connor, 2013). The premise of the theory is that reasons underlie human behavior. The focus is on an agent's own reasons for initiating an action rather than any external events that may stimulate an action (O'Connor, 2013). An agent has a reason to act when that action is a result of a desire-wanting to achieve something and a belief-confidence that by taking a specific action one would attain something desired (Davidson, 1963). Of course, reasons explain actions or deliberate inaction regardless of whether an agent's belief is correct. Similarly, whether a reason adheres to certain conventions or norms is also not critical for it to drive an action. Thus, the focus of action philosophers is on primary reasons-reasons that directly cause a specific action or inaction (Davidson, 1963), regardless of whether they comply with norms or achieve agent goals (Davis, 2013). 
Primary reasons describe what an agent wants to accomplish with an action (intent) and why it carries out that particular action (explanation) (Davis, 2013). "To know the primary reason why someone acted as (s)he did is to know an intention with which the action was done" (Davidson, 1963: 689). However, the concept of primary reason is broader than intention, comprising also explanation. "In explaining an action, we come to know why the agent acted as (s)he did; and to know why someone does something is to know the reason for his/ her doing it" (Everson, 2013: 145).

The causal theory of action also implies the counterfactual. When action is said to occur because of a primary reason $\mathrm{X}$, we also imply that it would not occur in the absence of $\mathrm{X}$ (Davis, 2013: 36). In other words, insufficient knowledge of the primary reasons for a specific action hobbles its interpretation. "When we ask why someone acted . . . we want to be provided with an interpretation. When we learn his/her reason, we have an interpretation ..." (Davidson, 1963: 691). Hence, it follows that understanding such reasons is essential for explaining and predicting competitive behavior. We build on the causal theory of action to garner insight into the reasons that inform rivalry.

In this study, we focus on primary reasons that explain why an agent initiates a particular competitive action. For example, a coach can substitute players (an action) because they were not disciplined in executing a particular tactic (the primary reason). Of course, this action can serve other goals such as improving performance. However, the latter are not primary reasons for the substitution and have limited predictive utility-it is of little value to know opponents made a substitution to perform better. Primary reasons, by contrast, provide more actionable information. Knowing a rival's action addresses a specific defensive failure can guide a coach toward a way to thwart that effort.

In short, we define competitive rationales as the primary reasons that directly explain why specific actions are initiated at a given moment and under specific circumstances. These rationales are conceptually distinct from less specific reasons explored in previous research, including superior capabilities, favorable market conditions, psychological states, and cognitive dispositions. The latter describe general conditions, dispositions, and goals that can trigger any action but do not explain why a particular action was initiated. We elaborate on these contrasts below.

\section{Competitive Rationales Versus Other Reasons Studied in Competitive Dynamics}

\section{Superior Capabilities}

As noted above, a common reason for carrying out competitive actions is said to be a firm's superior internal and external resources and capabilities (e.g., Andrevski et al., 2016; Carnes et al., 2019; Gnyawali \& Madhavan, 2001; Ndofor et al., 2011; Smith et al., 1991). Clearly, however, capabilities are not primary reasons for carrying out a particular action. They reflect a general potential to act but do not explain the specific reason why firms initiate a particular action at a given time and situation.

\section{Market Conditions}

Other studies have explored the role of market characteristics, such as centrality, identity domain, alliance network position, and multimarket contact in explaining competitive actions 
and responses (Chen \& Miller, 1994; Gnyawali \& Madhavan, 2001; Livengood \& Reger, 2010; McGrath et al., 1998; Yu \& Cannella, 2013). Market conditions can trigger multiple types of actions but do not differentiate between their rationales. They only define a precipitating context but cannot explain just what managers want to achieve.

\section{Subjective Perceptions of Competitors}

Other reasons for acting have been inferred from psychological experiences of rivalry and competitive tension (Chen et al., 2007; Kilduff et al., 2010). Again, these factors can stimulate actions but do not explain why a particular action occurred. For example, competitive tension might motivate a firm to cut prices because of a cost advantage or to match a rival's price cut. Alternatively, the firm might forbear from cutting prices in an effort to deescalate rivalry. Each of these rationales can be triggered by competitive tension. Thus, perceptions of rivals may tempt one to act, whereas primary reasons explain why an action occurred.

\section{Managerial Cognition}

Research on managerial cognition has examined factors that affect how executives notice and interpret rivals' actions (Marcel et al., 2010). Action and top management characteristics, firm information processing capabilities, and managers' cognitive frameworks affect how managers filter information, focus attention, and identify rivals (e.g., Hambrick et al., 1996; Nadkarni \& Barr, 2008; Nadkarni \& Chen, 2014; Smith et al., 1991). Such factors help to explain where managers direct their attention but not why they initiate a particular action. Noticing an action is quite different from knowing the reasons behind it. Like perceptions, cognitive dispositions are personal traits that predispose managers to take actions, but they do not explain why managers initiate a specific action.

\section{Why Study Competitive Rationales?}

Whereas previous research examined whether a competitor is able and likely to initiate a competitive attack or response, our study asks why a competitor initiates a particular action or response and what it intends to achieve with it, thereby directly linking cause and effect. According to the causal theory of action, "the explanation by reasons is a type of causal explanation" (Davis, 2013: 35). When we know the primary reason that causes an action, we can understand what an agent wants to accomplish and why a competitive action is carried out. For example, by studying the primary reasons, we can learn whether an action is directed to neutralize a rival's action or is primarily intended to address other organizational and social issues. We can also get a better understanding of the scope of its intended outcomes: Does it address the immediate situation or involve longer term objectives? Is it intended to deal with a current rival or primarily aimed at shaping relationships with other parties? Is it an integrative part of a broader strategy? Equally important, by focusing on primary reasons, we can distinguish competitive rationales from other reasons studied in previous competitive dynamics research.

Thus, in this study, we take initial steps toward developing a conceptual framework for studying competitive rationales. By leveraging an inductive approach, we surface key types and scope domains of competitive rationales that help to explain and predict tactical competitive behavior. 


\section{Method}

\section{Research Design and Setting}

To gain insight into the rationales for tactical actions, we collected qualitative data from interviews and observations of basketball coaches. We employed a multiple-case study approach to analyze data from multiple decision makers on multiple occasions (Eisenhardt, 1989). Although findings from sports settings are sometimes thought to be limited in generality, they are appropriate for studying tactical decision making such as that by midlevel brand or sales managers. Moreover, their advantages of unambiguous observation, precise measures, motivated participants, and few confounds have for decades enlightened organizational analysis (Day, Gordon, \& Fink, 2012; Wolfe et al., 2005). For example, studies of basketball and baseball provide insight into the nature of tacit knowledge, human capital, organizational status, strategy, and competitive advantage (Berman, Down, \& Hill, 2002; Poppo \& Weigelt, 2000; Sirmon, Gove, \& Hitt, 2008; Washington \& Zajac, 2005; Wright, Smart, \& McMahan, 1995). Sports also are a common domain for competitive dynamics scholars, especially those pursuing sociocognitive aspects of rivalry (Kilduff et al., 2010; 2016; Miller, Pastoriza, \& Plante, 2019; To, Kilduff, Ordonez, \& Schweitzer, 2018). For example, Kilduff et al. (2010) demonstrate revealingly how institutionalized rivalries shape the intensity of basketball play and outcomes.

As with other sports-related studies, our choice of a basketball coaching setting afforded several advantages for studying tactical behavior. First, a game unambiguously consists of two head-to-head rivals competing with visible actions that require little time and resources to execute. Second, when games are in progress, coaches must consider both the short-term and long-term impact of their actions on their team's capabilities, rivals, and stakeholders. Third, a member of our research team was granted proximate, complete, and unfiltered access to the primary reasons stated for each action or inaction during multiple games.

Basketball coaching also is a useful context for exploring tactical nuance and complexity. If tactical rationales are diverse, multifaceted, and potentially strategic within this temporally and resource-constrained context, these characteristics are apt to be even more prevalent in business, where managers have more time, resources, and competitive options to consider (see Table 2).

\section{Preliminary Interviews}

We decided on a basketball coaching setting only after conducting preliminary interviews with seven coaches from seven basketball clubs competing in the International Basketball Federation (FIBA) leagues as well as Canadian and United States college leagues (one of the authors was a professional player for 11 years in FIBA). Our meetings in June and July 2013 assessed the prevalence of tactical actions in their decision-making. We found that tactical forbearances - that is, deliberately deciding not to act for specific reasons-occurred frequently. These were captured in statements made by the coaches we interviewed, such as "we wanted to X . . . but we decided to hold back because." In this exploratory stage, we also assessed coaches' readiness and capacity to provide rationales. Their responses were encouraging, prompting us to develop a protocol to conduct postgame interviews with coaches to capture the rationales for their tactical behavior during games. 


\section{Table 2}

\section{Basketball Competition Versus Business Competition}

\begin{tabular}{lll}
\hline & Basketball Competition & Business Competition \\
\hline Action development time & Seconds to minutes & Months to years \\
Action development resources & Limited & Considerable \\
Competitive interaction duration & Periodic (quarter/game) & Open-ended \\
Decision makers & Few (head coach and two & Several (top managers \\
& assistant coaches) & and middle managers) \\
\hline
\end{tabular}

\section{Data}

\section{The Sample}

We relied on personal contacts with coaches and sports directors to contact the coaches of all 10 men's teams of a European country's first national league. Nine out of 10 coaches agreed to participate due to their familiarity with the first author. They were interviewed on more than one occasion as their teams participated in multiple games. This allowed us to collect data from multiple coaches and multiple games for each coach. In total, we conducted 30 postgame interviews with 9 head coaches about their tactical decisions in 15 basketball games in one European country (a member of the FIBA-Europe). We collected archival data for each coach and team from three sources: the statistical database of FIBA Europe, the basketball federation of the country in which we conducted interviews, and the videotaped games. Coaches, all male nationals, had diverse coaching experience (2-33 years), coaching success (0-6 championship titles), prior team rankings (from 2 nd to 10 th place in the previous season), and age (32-62 years).

We focused our data gathering on 15 regular season games taking place between October 19, 2013 and November 11, 2013. The set of games played on October 19 represented the second week of the 2013 to 2014 basketball season. We used the first week of gamesplayed on October 12, 2013 but not included in our sample - to test our video equipment, check the quality of the edited videos, get feedback from the coaches about the videos and their availability for interviews, and inform them about the interview protocol using the videos.

\section{Data Collection Procedures}

The lead author conducted all interviews to reduce person-specific inconsistencies in the data collection process (Corley \& Gioia, 2004). He was entirely familiar with basketball terminology and, again, had extensive professional basketball experience. Coaches were assured of confidentiality.

In collaboration with the basketball federation of the country, we hired a professional media firm to videotape each game using two camcorders: one to capture action on the basketball court and the other to capture information on the electronic scoreboard. The videos were then electronically spliced together to continuously show the game score, time period, and game clock time as the game was in progress. These videos were used in postgame interviews with the coaches to facilitate a retrospective analysis of the games and coaches' decisions. The lead author met with each coach within a couple of days after the 
game-whenever the coach was available - but before his next scheduled game. Eighteen of the 30 interviews $(60 \%)$ took place within two days of the focal game with another 5 interviews (cumulatively 77\%) within 3 days of the game. The remaining 7 interviews occurred within 6 days of the focal game.

The interviewer presented the following script to each coach before the interview (also included in the consent form):

As a basketball coach, you make many decisions during a basketball game, such as decisions to substitute a player, not take a timeout, change a play, or continue playing the same defensive formation. Thus, you are making decisions to act or not, for example, because you believe not changing would improve your team's performance. I will ask you to elaborate on the reasons why you chose to act or not to act at that time. I ask you to comment on all decisions you made during the game: decisions to act and decisions to purposefully not initiate a considered action.

Thus, our focus was on exploring the rationales - the primary reasons - for considered tactical actions or forbearances. We conducted interviews using two laptop computers: one for watching the game and one for taking notes. The coach was instructed to stop the video at any point during the replay of game when he considered a tactical move-whether carried out or not-such as changes in offensive or defensive tactics, player substitutions, and timeouts. Interviews lasted from 2 hours and 10 minutes to 2 hours and 55 minutes per game. As the interview progressed, the first author noted, in an Excel spreadsheet, critical facts associated with each coach-initiated stoppage of the video playback: the type of tactical move considered, the time and period of play displayed on the game clock, and the score of the game at that moment. Most importantly, for each coach-initiated video playback stoppage, the interviewer wrote verbatim the coach's detailed reason for carrying out — or not - the tactical action considered at that precise time. Table 3 presents numerous examples of various rationales translated from the coach's native language.

Our study employed retrospective interviews with coaches as they watched videos of their own games. Thus, tactical actions and rationales may have been underreported due to incomplete or inaccurate coach recollections. We tried to limit such recall bias by conducting interviews soon after a game. Also, our protocol never broached issues of the success or appropriateness of moves.

\section{Analysis}

Our data include 841 statements from coaches transcribed during the interviews describing their reasons for acting or not acting. Two authors with limited basketball knowledge and not involved in the data collection process coded the data together with the expert author who had collected that data (samples of the raw data are shown in Table 3). During the analysis, the expert-author described and clarified the meaning of any "technical" terms used by the coaches (e.g., zone press, pick-and-roll, pick-and-pop, switching in defense, boxing out, etc.). Coding was conducted collectively using both the lead author's expert interpretations and the other two authors' interpretations of coaches' statements.

In this "first-order" analysis, the three coders attempted to identify from coaches' statements all primary reasons for actions or inactions, proceeding until saturation was reached. This was an inductive iterative process involving two day-long in-person discussions among 


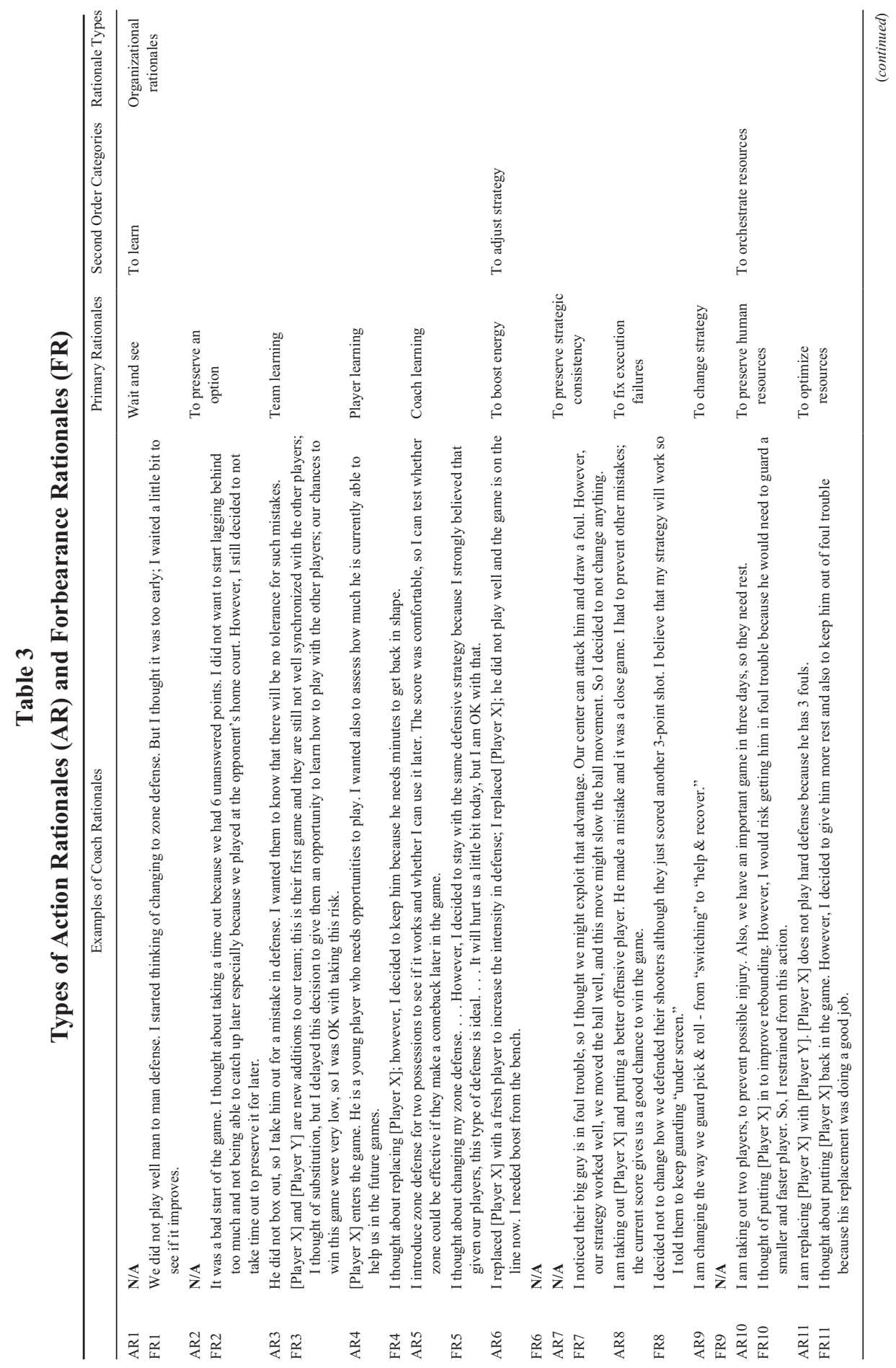




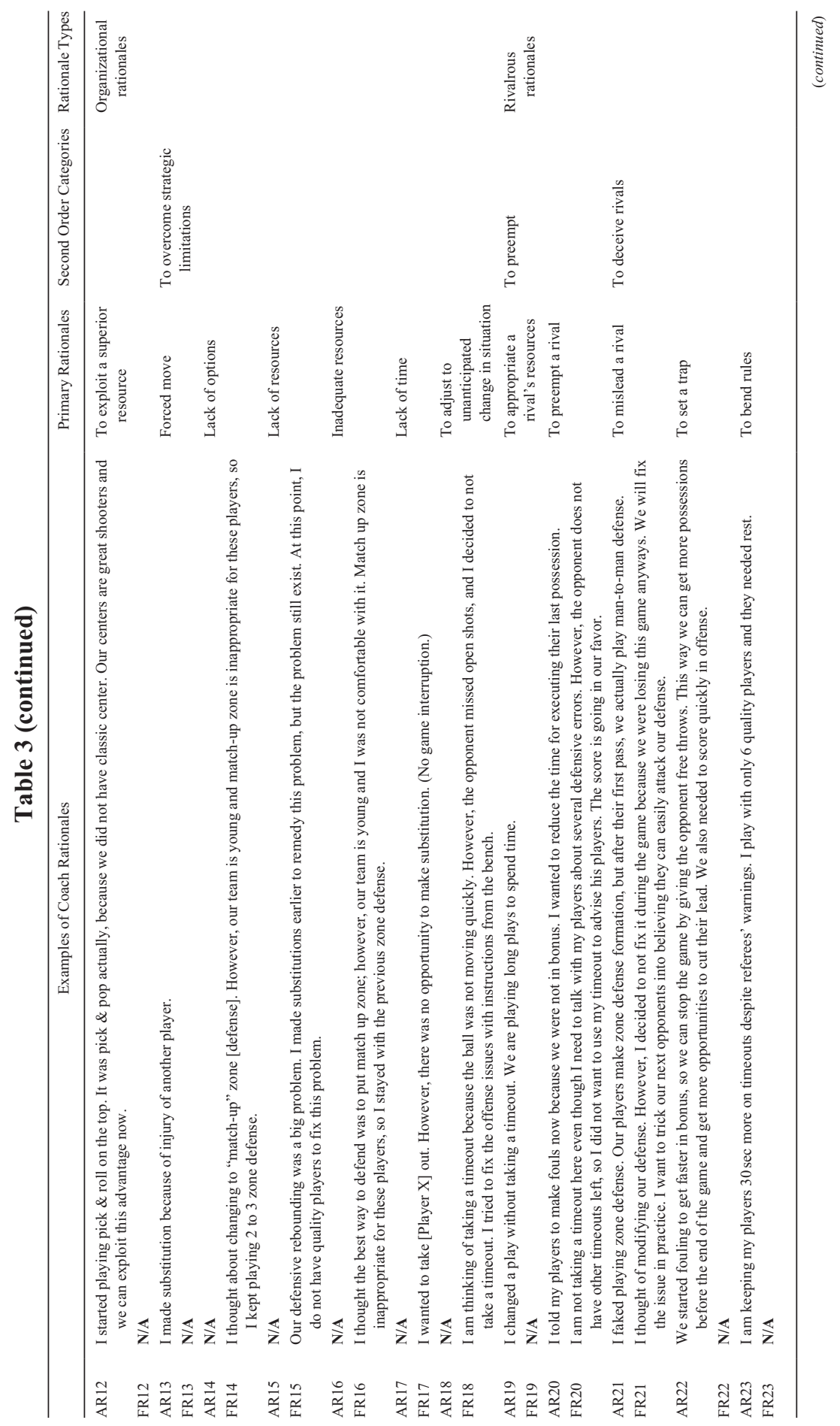




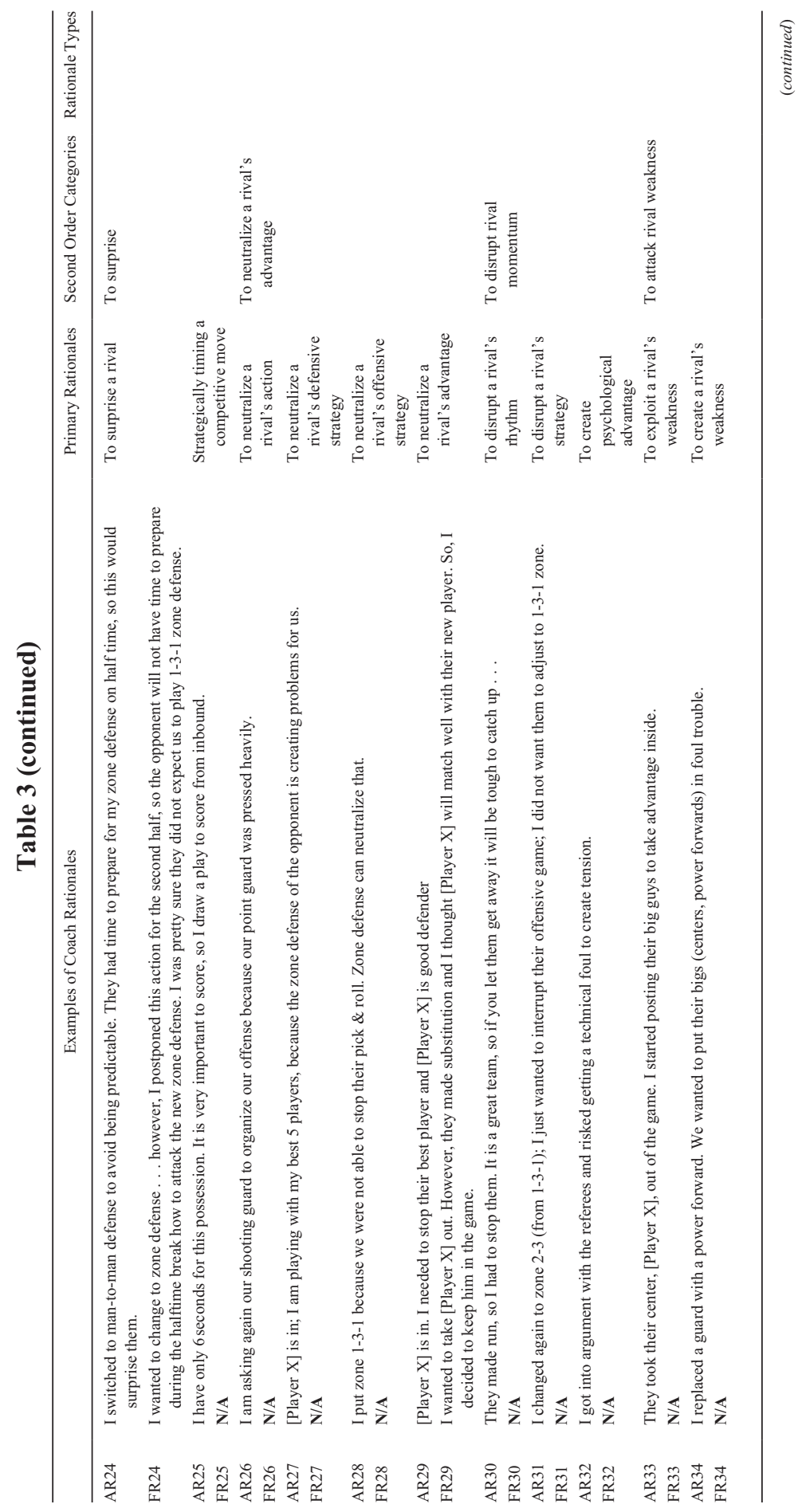




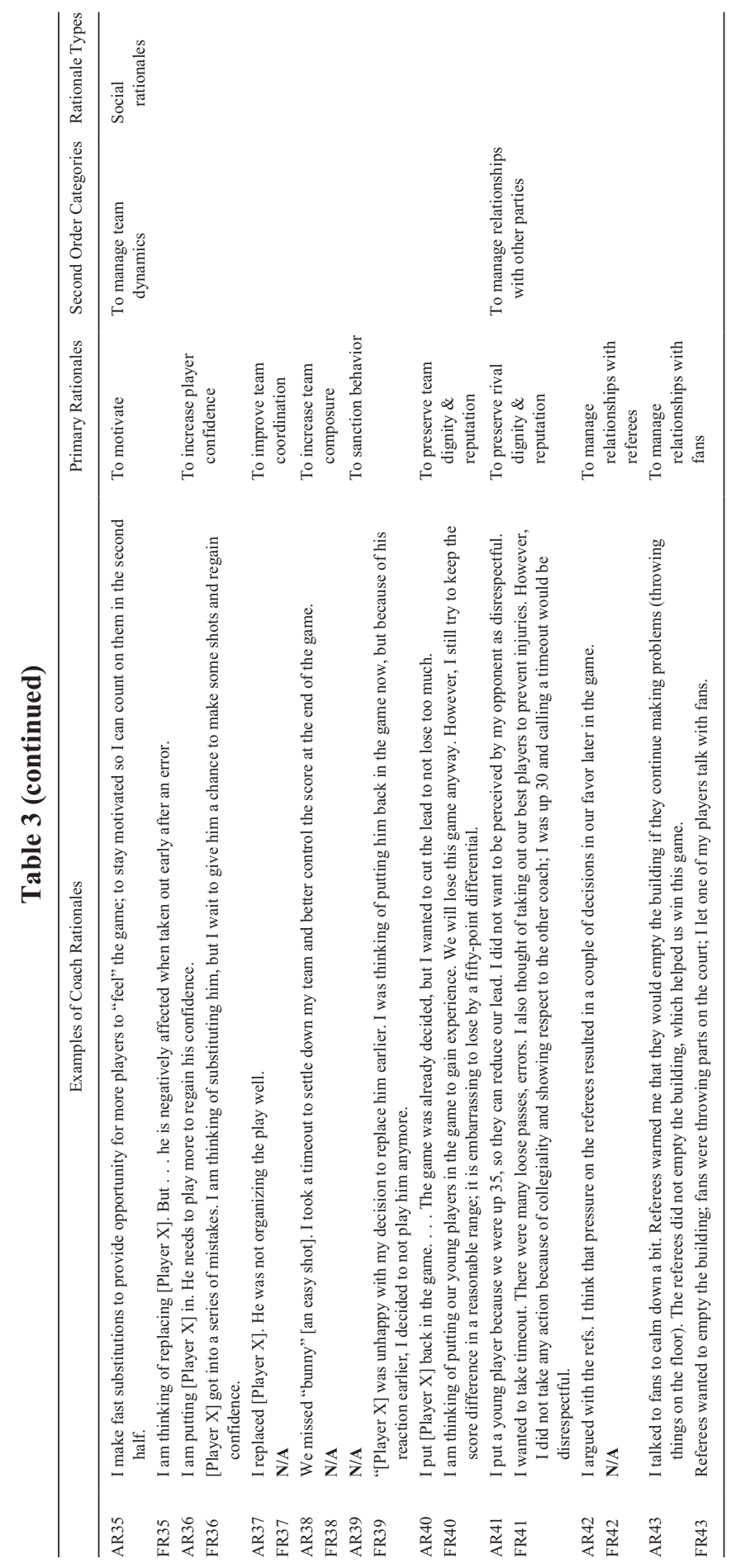


three authors (Grodal, Anteby, \& Holm, 2021). The authors generated labels for the rationales they believed were embodied in the coach statements, keeping the labels as close as possible to the coaches' terminology - for example, to surprise a rival, to preempt a rival, to enhance player learning, to increase player confidence, or to improve strategy execution (Gioia, Corley, \& Hamilton, 2013). Saturation level was reached after 300 analyzed statements, which covered the first five games. In fact, after the first 250 statements hardly any new rationales emerged. This analysis yielded 34 primary rationales for tactical actions and 24 for tactical forbearances (with some actions and forbearances having rationale types in common, yielding 43 rationales in total). Table 3 illustrates the hierarchical structure of our data, including translated representative coaches' statements for each of the 43 primary rationales.

In a second step, we searched for similarities across primary rationales and attempted to group them into more general, second-order categories (Grodal et al., 2021). To accomplish this reliably, two authors independently analyzed similarities among primary rationales and attempted to group them into more general categories (e.g., to learn, to adjust strategy, to orchestrate resources, to deceive rivals, to manage interpersonal relationships). Next, the three authors met to reconcile the categories, reaching agreement on 12 of them (in 3 cases where there was disagreement among the raters, separate categories were preserved). The expert author then went back to code all 841 statements. To establish coding reliability, another author blindly coded a random sample of a different set of 42 statements $(5 \%$ of the data). The resulting Perreault and Leigh's (1989) reliability index was 0.74 for second-order categories, above the prescribed 0.70 cutoff. $^{1}$

In revisiting statements within our primary rationales and their second-order categories, and through more discussion among the authors, we identified three overarching third-order rationale types. These are rivalrous, organizational, and social rationales. Rivalrous rationales prioritized a current and specific rival and its actions. Organizational rationales were primarily directed toward making organizational adjustments such as preserving resources, fixing execution failures, or maintaining strategic consistency. Finally, social rationales prioritized clearly relational and interpersonal issues - for example, to motivate, avoid embarrassment, or preserve rival dignity.

Within each of the three rationale types - rivalrous, organizational, and social - the three authors as a group revisited the primary rationales to discover the scope of their target domains, the second dimension of our framework (Tavory \& Timmermans, 2014). Rationales were found to vary according to temporal and strategic scope and the range of external parties considered beyond the current rival. This process identified three target domains - the immediate situation, longer term strategic outcomes, and other external parties. Together, the three rationale types, each reflecting three potential target domains, constitute the structure of our findings ( 9 cells, see Table 4 ). We classified the primary rationales accordingly. The authors reached consensus on most of the rationales identified by a unique cell in Table 4 (I to IX). In eight cases, the primary rationales were allocated to two cells. ${ }^{2}$

\section{Findings}

\section{Types of Competitive Rationales}

Whereas all tactical actions are competitive - that is, intended to improve performance vis-à-vis rivals - their primary reasons can be rivalrous, organizational, and/or social. 
Table 4

Conceptual Framework for Studying Competitive Rationales

\begin{tabular}{|c|c|c|c|}
\hline \multirow[b]{2}{*}{ Scope of Rationales } & \multicolumn{3}{|c|}{ Types of Rationales } \\
\hline & Rivalrous & Organizational & Social \\
\hline $\begin{array}{l}\text { Immediate situation } \\
\text { (immediate rival, } \\
\text { actions, and } \\
\text { outcomes) }\end{array}$ & $\begin{array}{l}\text { (I) } \\
\text { To preempt a rival } \\
\text { To neutralize a rival's action } \\
\text { To neutralize a rival's } \\
\text { advantage } \\
\text { To appropriate a rival's } \\
\text { resource } \\
\text { To disrupt rhythm } \\
\text { To set a trap } \\
\text { To surprise } \\
\text { To mislead } \\
\text { To defy/bend rules } \\
\text { Timing a move } \\
\text { To create/exploit rival's } \\
\text { weakness }\end{array}$ & $\begin{array}{l}\text { (IV) } \\
\text { To boost energy } \\
\text { To fix execution failures } \\
\text { To exploit superior resources }\end{array}$ & $\begin{array}{l}\text { (VII) } \\
\text { To increase team } \\
\text { composure/coordination } \\
\text { To sanction behavior }\end{array}$ \\
\hline $\begin{array}{l}\text { Longer term } \\
\text { strategic } \\
\text { outcomes } \\
\text { (longer term } \\
\text { vs. immediate } \\
\text { effects, and } \\
\text { overall strategy } \\
\text { vs. single tactical } \\
\text { action) }\end{array}$ & $\begin{array}{l}\text { (II) } \\
\text { To surprise current rival in } \\
\text { future game periods } \\
\text { To disrupt rival strategy } \\
\text { To neutralize rival strategy }\end{array}$ & $\begin{array}{l}\text { (V) } \\
\text { Team learning } \\
\text { Player learning } \\
\text { Coach learning } \\
\text { To wait and see } \\
\text { To preserve option } \\
\text { To preserve resources } \\
\text { To optimize resource usage } \\
\text { To change strategy } \\
\text { To preserve strategic } \\
\text { consistency }\end{array}$ & $\begin{array}{l}\text { (VIII) } \\
\text { To motivate players/team } \\
\text { To increase player } \\
\text { confidence } \\
\text { To preserve team dignity/ } \\
\text { reputation } \\
\text { To preserve rival dignity }\end{array}$ \\
\hline $\begin{array}{l}\text { External parties } \\
\text { beyond a } \\
\text { direct rival } \\
\text { (other external } \\
\text { stakeholders vs. a } \\
\text { direct opponent) }\end{array}$ & $\begin{array}{l}\text { (III) } \\
\text { To mislead and conceal a } \\
\text { move from future rivals } \\
\text { To create psychological } \\
\text { advantage by getting in } \\
\text { argument with referees }\end{array}$ & $\begin{array}{l}\text { (VI) } \\
\text { To develop resources for } \\
\text { competing against future rivals }\end{array}$ & $\begin{array}{l}\text { (IX) } \\
\text { To calm fans } \\
\text { To influence referees }\end{array}$ \\
\hline
\end{tabular}

Rivalrous rationales are reasons with a primary purpose, for example, to outwit competitors, disrupt rival rhythm, mislead current and future rivals, or neutralize rival strategy. Organizational rationales are reasons related to organizational adjustments. Although these rationales can ultimately affect performance and thus rivals, their primary intent is to address the organization itself, not rivals or their actions. Finally, social rationales deal primarily with relational and interpersonal issues. They address norms and expectations of various stakeholders and manage team dynamics.

Even in a highly competitive zero-sum situation, 74\% of all rationales mentioned by coaches sought to improve the general capacity to compete through improved organization. For example, they substituted players not to attack or respond to an opponent but primarily for organizational reasons such as nurturing resources and ensuring strategic coherence. 
Three hundred and fifty (42\%) rationales related to adjusting strategy, $213(25 \%)$ to organizational learning and orchestrating resources, and $58(7 \%)$ to dealing with strategic limitations. Social rationales surfaced here, too, in maintaining morale and confidence and protecting the dignity of opponents and others. Twenty-three nonrivalrous rationales were initiated for social reasons $(3 \%)$, while the rest were rivalrous $(23 \%)$.

Competition in business, too, is not simply a matter of responding to rivals or attacking them. Firms must build organizationally and socially while in the heat of competition in order to become more effective. For a responder to erroneously assume that an action is backed by rivalrous intent can lead to retaliatory responses that unnecessarily escalate rivalry.

\section{Scope of Competitive Rationales}

Our second dimension considers how rivalrous, organizational, and social rationales differ in scope across the three target domains of immediate situation, long-term strategic outcomes, and other external parties. As noted, Table 4 juxtaposes the three rationale types and three target domains of rationales. Each cell in the table embeds the primary rationales that most closely correspond to each rationale type and target domain.

The first target domain - the immediate situation-describes rationales primarily concerned with a direct rival, action, and its immediate effects (within the same quarter of the game or a single exchange). Typically, these rationales aim to neutralize a rival's specific action, exploit sudden opportunities to score, and prevent execution failures. The second domain comprises rationales with a longer term and strategic orientation. They seek benefits over multiple exchanges and periods of the game and possibly even beyond a current game; they mainly focus on achieving broader, strategic purposes such as disrupting rival strategy, testing and modifying one' own strategy, and protecting reputation. The third domain captures rationales that deal with a team's external parties other than a direct rival, which include future rivals, fans, and referees. ${ }^{3}$

The types and scope of rationales are common for both actions and forbearances. Coaches often used forbearance for rivalrous, organizational, and social reasons - they were especially instrumental for achieving longer term and systemic/strategic goals. We identified 673 rationales for action (80\%) and 168 for forbearance (20\%) (see Table 5).

\section{Competitive Rationales Framework}

\section{Rivalrous Rationales}

As noted, rivalrous rationales are directed toward acting or responding directly to opponents. Their target domain may be the immediate rival and outcomes, longer term strategic moves directed to rivals, and other external parties in the competitive exchange.

Immediate situation. Given the traditional focus of the competitive dynamics literature, it was not surprising that many actions were rivalrous; that is, intended to outmaneuver opponents at a given moment in time. The first set of rivalrous rationales (Cell I in Table 4) deals with direct rivals and immediate action outcomes. Some of these rationales have to do with surprising, confusing, and deceiving an opponent. Coaches deployed tactics to throw rivals 
Table 5

Competitive Rationales by Actions and Forbearances

\begin{tabular}{|c|c|c|c|c|c|c|c|c|}
\hline \multicolumn{4}{|c|}{ Rationale Categories } & Action & \multicolumn{2}{|c|}{ Forbearance } & Total & Percentage \\
\hline \multicolumn{4}{|c|}{ Organizational } & 477 & \multicolumn{2}{|c|}{144} & 621 & \multirow[t]{5}{*}{74} \\
\hline \multicolumn{4}{|c|}{ To adjust strategy } & 312 & \multicolumn{2}{|c|}{38} & 350 & \\
\hline \multicolumn{4}{|c|}{ To learn } & 52 & \multicolumn{2}{|c|}{55} & 107 & \\
\hline \multicolumn{4}{|c|}{ To orchestrate resources } & 87 & \multicolumn{2}{|c|}{19} & 106 & \\
\hline \multicolumn{4}{|c|}{ To overcome strategic limitations } & 26 & \multicolumn{2}{|c|}{32} & 58 & \\
\hline \multicolumn{4}{|c|}{ Rivalrous } & 183 & \multicolumn{2}{|c|}{14} & 197 & \multirow[t]{7}{*}{23} \\
\hline \multicolumn{4}{|c|}{ To attack a rival's weakness } & 64 & & 64 & \\
\hline To deceive & vals & & & 8 & & 5 & 13 & \\
\hline To disrupt & al mome & & & 35 & & 1 & 36 & \\
\hline To neutral & a rival's & vantage & & 49 & & 3 & 52 & \\
\hline To preemp & rival & & & 11 & & 3 & 14 & \\
\hline To surpris & & & & 16 & & 2 & 18 & \\
\hline Social & & & & 13 & & 0 & 23 & 3 \\
\hline To manag & lationshi & with other par & ties & 7 & & 5 & 12 & \\
\hline To manag & am dyna & & & 6 & & 5 & 11 & \\
\hline Grand total & & & & 673 & $1 \mathrm{r}$ & & 841 & 100 \\
\hline & Num & of Rationales & & & & & & \\
\hline Coach ID & Action & Forbearance & Total & Forbearances & Age & Experience & Won & Up \\
\hline Coach 1 & 81 & 35 & 116 & 30 & 62 & 33 & 6 & 5 \\
\hline Game 1 & 25 & 17 & 42 & 40 & & & & \\
\hline Game 5 & 26 & 9 & 35 & 26 & & & & \\
\hline Game 11 & 30 & 9 & 39 & 23 & & & & \\
\hline Coach 2 & 62 & 12 & 74 & 16 & 40 & 4 & 1 & 1 \\
\hline Game 1 & 21 & 8 & 29 & 28 & & & & \\
\hline Game 6 & 18 & 2 & 20 & 10 & & & & \\
\hline Game 9 & 23 & 2 & 25 & 8 & & & & \\
\hline Coach 3 & 51 & 2 & 53 & 4 & 44 & 3 & 0 & 1 \\
\hline Game 2 & 15 & 1 & 16 & 6 & & & & \\
\hline Game 8 & 16 & & 16 & 0 & & & & \\
\hline Game 15 & 20 & 1 & 21 & 5 & & & & \\
\hline Coach 4 & 105 & 18 & 123 & 15 & 40 & 4 & 0 & 0 \\
\hline Game 2 & 27 & 5 & 32 & 16 & & & & \\
\hline Game 7 & 24 & 4 & 28 & 14 & & & & \\
\hline Game 11 & 27 & 4 & 31 & 13 & & & & \\
\hline Game 14 & 27 & 5 & 32 & 16 & & & & \\
\hline Coach 5 & 80 & 14 & 94 & 15 & 47 & 16 & 1 & 3 \\
\hline Game 3 & 19 & 4 & 23 & 17 & & & & \\
\hline Game 6 & 17 & 3 & 20 & 15 & & & & \\
\hline Game 10 & 18 & 1 & 19 & 5 & & & & \\
\hline Game 14 & 26 & 6 & 32 & 19 & & & & \\
\hline Coach 6 & 68 & 19 & 87 & 22 & 44 & 4 & 0 & 1 \\
\hline Game 3 & 17 & 8 & 25 & 32 & & & & \\
\hline
\end{tabular}


Table 5 (continued)

\begin{tabular}{|c|c|c|c|c|c|c|c|c|}
\hline \multirow[b]{2}{*}{ Coach ID } & \multicolumn{3}{|c|}{ Number of Rationales } & \multirow{2}{*}{$\begin{array}{c}\% \\
\text { Forbearances }\end{array}$} & \multirow{2}{*}{$\begin{array}{l}\text { Coach } \\
\text { Age }\end{array}$} & \multirow{2}{*}{$\begin{array}{l}\text { Headcoach } \\
\text { Experience }\end{array}$} & \multirow{2}{*}{$\begin{array}{c}\text { Championships } \\
\text { Won }\end{array}$} & \multirow{2}{*}{$\begin{array}{l}\text { Runner } \\
\text { Up }\end{array}$} \\
\hline & Action & Forbearance & Total & & & & & \\
\hline Game 9 & 22 & 8 & 30 & 27 & & & & \\
\hline Game 13 & 29 & 3 & 32 & 9 & & & & \\
\hline Coach 7 & 102 & 28 & 130 & 22 & 32 & 2 & 0 & 0 \\
\hline Game 4 & 26 & 16 & 42 & 38 & & & & \\
\hline Game 7 & 26 & 7 & 33 & 21 & & & & \\
\hline Game 12 & 30 & 2 & 32 & 6 & & & & \\
\hline Game 15 & 20 & 3 & 23 & 13 & & & & \\
\hline Coach 8 & 83 & 16 & 99 & 16 & 44 & 5 & 0 & 1 \\
\hline Game 4 & 23 & 9 & 32 & 28 & & & & \\
\hline Game 5 & 20 & 2 & 22 & 9 & & & & \\
\hline Game 10 & 24 & 4 & 28 & 14 & & & & \\
\hline Game 13 & 16 & 1 & 17 & 6 & & & & \\
\hline Coach 9 & 41 & 24 & 65 & 37 & 36 & 6 & 4 & 2 \\
\hline Game 8 & 19 & 21 & 40 & 53 & & & & \\
\hline Game 12 & 22 & 3 & 25 & 12 & & & & \\
\hline Grand total & 673 & 168 & 841 & 20 & & & & \\
\hline
\end{tabular}

off their game, specifically, to disrupt their rhythm (Table 3-AR30), set a trap (AR22), surprise them (A24; F24), or mislead them (AR21; FR21). ${ }^{4}$ For example, a coach attempted to negate rival momentum by telling players "to make quick non-shooting fouls" (Coach 2, Game 1 (C2, G1) in our data). Another coach took a timeout to disrupt his rival's rhythm: They scored several unanswered points. I took a timeout to stop their run (C5; G3). Coaches also initiated actions to set a trap for the opponent: We started fouling [in the last two minutes of the fourth quarter] to get faster in bonus, so we can stop the game by giving the opponent free throws. This way we can get more possessions before the end of the game (AR22). One coach unexpectedly changed his defense after a timeout to surprise the opponent: I changed to zone defense after a timeout; I wanted to surprise them (C8; G4). Another coach attempted to surprise more regularly: We alternate every other possession between zone and man-toman defense to confuse them and stay unpredictable (C6; G9).

Coaches also attempted to deceive opponents: There were 2 seconds left. I called Player $X$ to come talk to me. I told him to stay and pretend as if he is talking to me. Then, I told him to suddenly sprint and try to score by surprise (C9, G12); they also intended to mislead with forbearance: I faked playing zone defense. Our players made a zone defense formation, but after their first pass, we actually played man-to-man defense (AR21). A coach even attempted to avoid strictly following the rules: I am keeping my players 30 seconds more on timeouts despite referees' warnings. I play with only 6 quality players and they needed rest (AR23). Other rationales were more typical of prior work in competitive dynamics. For example, coaches initiated actions and forbearances to preempt rivals (AR20; FR20) and to neutralize their actions (AR26) and advantages (AR29; FR29) (e.g., Chen \& Miller, 2012; Ma, 1999; Porter, 2008).

In summary, this set of rivalrous rationales primarily deals with the current and immediate competitive situation using a variety of tactical actions to outmaneuver opponents. 
Longer term strategic outcomes. Other rivalrous rationales focused on achieving benefits beyond the immediate situation and beyond single moves to achieve longer term strategic goals (Cell II, Table 4). For example, we identified forbearances that were initiated to achieve longer term benefits, such as preserving moves to use as surprises later in the game: I anticipated that the opponent would instruct his team how to attack 2-3 zone during the time out, so my intent was to surprise him with 1-3-1 zone defense. So I postponed this action to the second half (C1; G5; FR24). Another coach identified a problem but decided not to address it with a contemplated action: I feel that our man to man defense is weak. I am thinking now of trying a new type of defense (i.e., matchup zone), but I decided not to because I wanted to keep this defense as a surprise later (C1; $\mathrm{G} 1)$. The rationales for these forbearances go beyond creating short-term advantages to achieve a stronger position in the future.

Other competitive actions were initiated to influence a rival's overall strategy rather than address any particular move. For example, a coach initiated a move to interrupt a rival's strategy: I changed again to zone 2-3 (from 1-3-1); I just wanted to interrupt their offensive game; I did not want them to adjust to 1-3-1 zone (C1; G5). A coach also attempted to neutralize an opponent's defensive strategy: They were playing zone defense; I quickly reacted telling our team to change our offense (C4; G2).

Other external parties. Rivalrous rationales concern not only current rivals but also other parties involved in a current or future competitive context (Cell III, Table 4). For example, some coaches used forbearances to conceal their intentions from future rivals: I decided not to fix (a defensive error) because we were losing this game anyways. We will fix the issue in practice. I want to trick our next opponents into believing they can easily attack our defense (FR21). One coach intentionally argued with the referees to increase competitive tension and create psychological advantage over an opponent: I got into an argument with the referees and risked getting a technical foul to create tension (AR32).

Collectively, the above statements make clear that although rivalrous rationales were primarily intended to outmaneuver current rivals, they differ in short-term versus longer term objectives, specific moves versus systemic strategic ones, and a focus on direct rivals versus other parties. This signals a range, complexity, and subtlety in rivalrous rationales hitherto unanticipated in the literature.

Business relevance. Our exploration of rivalrous rationales has surfaced neglected issues that challenge managers' ability to interpret the competitive landscape. These include purposeful deception and forbearance, systemic and strategic timing of moves, considerations regarding future competitive engagements, and dealing with multiple stakeholders beyond a single rival. Clearly, in business situations where timing, disruption, and surprise are of the essence, these factors are likely to figure prominently.

\section{Organizational Rationales}

Organizational rationales are directed primarily towards improving team resources, strategy, and execution. As with rivalrous rationales, their target domains may be the immediate competitive situation, longer term strategy-related organizational moves rather than singular moves, and other parties. 
Immediate situation. The first set of organizational rationales were primarily concerned with quickly fixing internal failures in execution, intensifying effort, and exploiting resources (Cell IV, Table 4). For example, some coaches addressed immediate issues with execution: I took a timeout because of a bad pass. Our transition defense was also bad, we needed to fix this (C3; G2). I replaced [Player X]; he did not do a good job in defense (C7; G4). I took a timeout; we must move the ball faster. . . (C2; G1). Some actions were initiated to bring new energy: I put [Player X] in. I wanted to refresh my team, to bring more energy (C1; G5). I started playing full court pressing to try to reduce their lead (C4; G2). I put [Player X] in to enhance our offense; he is a very athletic player who can also help us with rebounding in defense (C5; G3). Other actions were intended to exploit a superior resource: I started playing 'pick \& pop.'. . Our centers are great shooters and we can exploit this advantage now (AR12).

Longer term strategic outcomes. Other organizational rationales were concerned with longer term outcomes (Cell V, Table 4). For example, some actions were initiated primarily to learn through experience: I put [Player X] back in the game. I wanted to give him a chance to play more, so I will know whether I can count on him for other games and which of his qualities can help my team $(\mathrm{C} 1 ; \mathrm{G} 1)$. Another coach chose to forbear for similar reasons: I am thinking of taking a timeout but I will wait because I want my players to struggle and learn how to deal with adversity $(\mathrm{C} 1 ; \mathrm{G} 1)$. This experiential process was initiated to gain longer term benefits, sometimes even beyond the current contest.

Forbearances, quite common in this category, were also employed when coaches wanted to reduce uncertainty by using a wait-and-see approach: I thought about making a sub but waited a little bit because the score was favorable (C2; G1). We committed two errors; I am thinking of taking a timeout to prevent further score decline. But I will wait two more attacks (C8; G4). At other times, forbearances were intended to preserve options: I needed to call a timeout, but I decided to keep it for my last two attacks, to organize them, so we can finish successfully (C7; G4).

Furthermore, coaches regularly initiated actions with a primary purpose to optimize resources (AR11): I took [Player X] out, [Player Y] in. I just wanted to keep both players in rotation (C6; G3). Other coaches stated: I replaced [Player X] and [Player Y]. I wanted to rest players and put fresh players in (C6; G9). Coaches also acted to preserve players for more opportune moments: I replaced Player X. . he was in foul trouble and I wanted to save him for the 4th quarter (C6; G13). Forbearances were also intended to preserve resources (FR10; FR2): I thought of putting [Player X] to improve rebounding. However, I would risk getting him in foul trouble because he would need to guard a smaller and faster player. So, I restrained from this action (C9; G8). Another coach preserved an option to use a timeout at a later time: I decided not to take a timeout to preserve it for later [when our team needs to rest] (C4; G2).

Some actions were initiated to change strategy (AR9), We change our defense from "hedging" to "switching" pick \& roll (C7; G7), and make strategic adjustments (AR8), I took a timeout. Our offense was stagnant and I wanted to speed up the game (C5; G10). Other coaches said they avoided taking actions that could slow execution: I noticed their big guy is in foul trouble, so I thought we might exploit that advantage. However, our strategy worked well, we moved the ball well, and this move might slow the ball movement [killing our momentum]. I decided to not change anything (FR7). They also prevented clashes with 
strategy: I recognized an opportunity to exploit a mismatch. . . However, I decided to not do that because I did not want my players to get out of our system [of play] . . to start playing individually (C7; G4).

Finally, actions were carried out to test strategy: I put in zone defense for two possessions to see if it works and whether I can use it later. The score was comfortable, so I can test whether zone could be effective (AR5). Similarly, one coach tried out a new defense in a game situation: I changed into zone defense; we just want to try how it will work; there is not much time left in the game to hurt us, but we can learn from it (C6; G3).

Other external parties. Beyond the current game, coaches initiated actions and forbearances to improve their team's capabilities for competing against future rivals (Cell VI, Table 4). For example, a coach made substitution to test whether a player can be effective with the next opponents: I put [Player X] back in the game. I wanted to give him a chance to play more, so I will know whether I can count on him for the next games and which of his qualities can help my team (C1; G1). Another coach used forbearance to integrate new players in the team: Player $X$ and $Y$ are new additions to our team . . . not familiar with our defensive schemes . . not synchronized with the other players. I thought of substitution, but I give them opportunity to learn how to play with the other players. Our chances of winning this game are very low . . I am thinking about the next opponent (C1; G1).

Collectively, organizational rationales varied in their orientation to orchestrate resources, create learning opportunities, or make strategic adjustments. In the short run, some rationales addressed execution failures and increasing team intensity. In the long run, other rationales focused on real-time learning, preserving options, and optimizing resources. Not surprisingly, rationales for crafting strategy had a longer term orientation. Additionally, there were several rationales related to organizational limitations such as forced substitutions of players due to lack of time (FR17), injuries (AR13), or inadequate skills (FR14, FR15, FR16). We do not include those in Table 4 because they indicate involuntary decisions rather than purposeful actions or forbearances.

Business relevance. Competitive advantage is achieved, in part, through a firm's ability to develop, nurture, and leverage superior resources. Conventional wisdom holds that managers develop resources primarily through strategic investments. Organizational rationales, by contrast, highlight the role of tactical competitive moves in enhancing current and longer term organizational capabilities. Indeed, rationales involving pacing and resource management, enduring consequences of engagement, parties beyond an immediate competitor, and the subtle orchestration of moves are likely to be critical in today's complex, dynamic business context.

\section{Social Rationales}

Social rationales are directed toward improving interpersonal relationships with internal (e.g., players) and external parties (e.g., rivals, fans) to enhance competitive effectiveness. Again, its target domain may be the immediate competitive situation, longer term strategic outcomes, and external parties. 
Immediate situation. Some rationales were aimed at quickly dealing with players' appropriate or inappropriate behavior (Cell VII, Table 4). For example, one coach attempted to improve the immediate competitive position by increasing player discipline: I tried to settle down my team; regardless of the score, we must play in a disciplined manner (C2; G9). Another coach dealt directly with players' performance by sanctioning them: I took Player $X$ out [because] he did not follow instructions (C1; G11). I did not want [Player Y] to be in the game at all; I was very mad at him! (C4; G14). Social rationales also dealt with increasing team composure or coordination: We missed "bunny" [an easy shot]. I took a timeout to settle down my team and better control the score at the end of the game (AR38).

Longer term strategic outcomes. Cell VIII in Table 4 illustrates rationales primarily intended to motivate players, increase their confidence, and preserve team dignity that could improve team performance beyond a current game and immediate action (AR35, 36, 40; FR35, 36, 40). For example, a coach stated: Player $X$ needs rest, whereas Player $Y$ is an older player, I want [Y] to feel involved in the game (C6, G3); the same coach made another substitution: I am putting [Player X] in. He needs to play more to regain his confidence (C6; G3). Other coaches used sanctions to set an example and as a socialization tool: I took [Player X] out for a mistake in defense. I wanted [my team] to know that there will be no tolerance for such mistakes (C7; G4). Another coach chose forbearance for a similar reason: [Player X] was unhappy with my decision to replace him earlier. At this time, I was thinking of putting him back, but because of his reaction earlier, I decided to not play him anymore (C6; G13). Finally, coaches' rationales considered other strategic outcomes such as preserving team reputation: I put [Player X] back in the game. . . . The game was already decided, but I wanted to cut the lead to not lose too much [in the eyes of fans] (AR41).

Other external parties. Coaches also actively managed other parties (Cell IX, Table 4). For example, one coach acted to calm fans (AR43), I talked to fans to calm them down a bit (C9, G8), and influence referees (AR42), Several times I argued with referees about calling a 'moving screen' $(\mathrm{C} 4, \mathrm{G} 2)$. Another coach took action to protect rival dignity and maintain a positive relationship: I put a young [inexperienced] player because we were up 35 points, so they (the opponent) could reduce our lead. I did not want to be perceived by my opponent as disrespectful (C6; G3).

Collectively, social rationales focused mostly on managing interpersonal relationships and team dynamics. In the short run, coaches acted to enhance team composure and sanction behavior, managing morale and team socialization. In the long run, they were more focused on motivating players and dealing with high-level strategic issues related to preserving team and rival reputation. They also managed other parties such as future rivals, fans, and referees.

Business relevance. Beyond the challenges associated with head-to-head rivalry, managers in business also need to be responsive to a wide range of stakeholders, such as suppliers, regulatory bodies, labor unions, environmental and social advocacy organizations, and the communities in which the firm operates. Our findings on social rationales suggest that managers carry out some tactical actions to address the complex motivations and emotions of salient social actors even in situations with high levels of competitive pressure. These social 
rationales therefore carry potential relevance to both the study and practice of competitive dynamics.

\section{Implications}

The theory of causal action (Davis, 2013; Davidson, 1963; O'Connor, 2013) represents a useful foundation for assessing the human deliberations underlying competitive behavior to get at its underlying causes - that is, the primary reasons for why an action does or does not take place. It extends competitive dynamics beyond external cues from markets and firms to explain competitive behavior, deepening our understanding of how competitors behave and why they act or forbear in specific situations.

We find that competitive behavior involves an astonishing variety of primary reasons for the same types of tactical actions. Specifically, our basketball coaches considered four observable types of competitive actions: player substitution, timeout, defense change, and offense change. By contrast, as noted, we identified 43 primary rationales, many of which could drive a single type of action. For example, Table 3 shows the many rationales motivating player substitution..$^{5}$ In addition, rationales were often intended to mislead, surprise, or forbear, rendering them potentially inscrutable. Furthermore, coaches differed greatly in their rationale repertoires - posing further challenges to interpretation. Coach rationales per game ranged from 16 to 42 (see Table 5). ${ }^{6}$ Such complexity and inscrutability poses serious challenges for interpreting rival behavior.

Our conceptual framework takes initial steps toward developing a theory for interpreting competitive actions. It reveals the key types and target domains of primary rationales. The three types of primary reasons - rivalrous, organizational, and social-indicate what managers prioritize with a particular action; that is, dealing with rivals' actions, making organizational adjustments, or managing interpersonal issues. That specifies the reasons for an action. The framework also sheds light on the target domains or scope of each rationale: immediate issues versus long-term objectives, a single action versus strategy, and a direct opponent versus other stakeholder. Thus, our findings extend competitive dynamics research by getting behind "observable indicators to discover the perceptions and motivations that give rise to observable market actions" (Chen \& Miller, 2012), in the process provoking a reevaluation of the AMC framework.

\section{Implications for the AMC Model}

The AMC model has served as a central pillar for studying competitive action and response (e.g., Chen, 1996; Chen et al., 2007; Chen \& Miller, 1994, 2012; Tsai, Su, \& Chen, 2011). Our findings have implications for each of the model's three components: awareness, motivation, and capability. First, our research suggests that the study of rationales can expand and deepen our characterization of competitor awareness, revealing hitherto unrecognized challenges to interpreting rival actions. Second, primary rationales explain motivations to act or forbear, reflecting longer term aims, parties beyond rivals, and broader strategic goals. Third, whereas prior research emphasized how capabilities drive competitive actions, we also find the reverse - that tactical actions build capabilities - for example by preserving and orchestrating resources to gain advantage in future periods. We discuss these findings below. 


\section{Awareness}

Prior research has focused on factors influencing how managers identify, monitor, and perceive rivals and how they come to be aware of their actions (Chen \& Miller, 2012). However, one can be aware of rivals and their actions, while not comprehending their rationales. Thus, understanding competitive rationales is essential for full awareness. Without it, actions remain opaque to interpretation. This can be challenging as our findings have shown that rationales are collectively complex and potentially inscrutable.

First, they differ across our types and target domains. They can be not only rivalrous but organizational and social, involving internal, relational, and strategic purposes difficult to detect or understand. They may address situations beyond a current attack, opponent, or short-term outcome to pursue undetectable purposes, such as preserving options, managing relationships with other parties, and concealing strategies. The resulting inscrutability is especially challenging as many rationales are purposely obscure, deceptive, and surprising (Guidice, Alder, \& Phelan, 2009; Hendricks \& McAfee, 2006). A second challenge to awareness is that rationale diversity - the range of rationale types - is far richer and broader than action diversity because multiple rationales can drive a single action.

Research on action-response dyads finds that awareness is influenced by an action's observable characteristics - radicality, irreversibility, implementation requirements, and noteworthiness - all of which determine the likelihood and speed of response (Chen, Smith, \& Grimm, 1992; Smith, Grimm, Chen, \& Gannon, 1989). Our study recasts that externally imputed portrait of awareness, the limits of which surface when complex and inscrutable rationales hobble effective response. Similar limitations also apply to research on competitive repertoires, sets of competitive actions carried out by firms over a given period (Connelly et al., 2017; Ferrier et al., 1999; Miller \& Chen, 1994). Simple repertoires with few types of actions are said to hurt performance (Miller \& Chen, 1996). However, we find that identical actions can be motivated by many different rationales, making even simple repertoires potentially inscrutable and effective.

These findings enrich our appreciation of the potential subtlety, complexity, and challenges of competitive engagement in business. Indeed, if tactical rationales are so diverse, deceptive, temporarily nuanced, and broadly contextualized in basketball, that may also hold in business situations. There, managers with different priorities from different departments make decisions in a context of multiple rivals and stakeholders on a range of rival-directed, organizational, and social issues. Under such conditions, interpreting and explaining rivals' rationales could be far more challenging than merely noticing their actions. Thus, our study suggests other aspects of awareness for scholars to consider in the AMC model: (1) To what extent can competitors distinguish rivalrous from social and organizational rationales? (2) How can managers assess rationale scope: for example, immediate situation versus longer term strategic goals and external parties? (3) How can managers recognize deceptive and misleading rationales?

\section{Motivation}

Competitive rationales disclose a multitude of motivations to act and respond or forbear. In prior studies, the motivation component of AMC concerned economic incentives and psychological motivations to act or respond in a competitive situation (e.g., Kilduff et al., 2010; 
Kilduff, Galinsky, Gallo, \& Reade, 2016; Livengood \& Reger, 2010; To et al., 2018; Tsai et al., 2011; Withers, Ireland, Miller, Harrison, \& Boss, 2018). However, coach rationales divulge social and organizational motivating reasons for both action and inaction (Alvarez, 2010; Davidson, 1963; O'Connor, 2013). Our discussion of awareness illustrated the inscrutability of such motivations.

This challenge is compounded as forbearance reflected a critical and largely invisible and temporally conditioned effect of motivation. Forbearance occurs when managers are aware of an action and capable of responding, but for strategic purposes are motivated to not respond immediately (Andrevski \& Miller, 2020). Table 5 shows that $112(67 \%)$ of forbearance rationales were long-term and strategic (to adjust strategy, to orchestrate resources, and to learn). In our study, coaches chose forbearance to create later advantage over rivals, such as to surprise and mislead them in the future, preserve an option for more opportune use, take time to learn from experience, or grow capability. Forbearances also pursued longer term strategic organizational benefits, such as preserving strategic consistency or concealing a new strategy from future rivals. Thus, "managers will often strategically forbear when they look at the broader context of an attack, considering it in the light of parties other than the attacker, longer-term past and future events, and more systemic aspects of strategic cohesiveness and adaptation" (Andrevski \& Miller, 2020: 10). It is important, therefore, that future scholars using the AMC model consider forbearance as a core aspect of motivation.

Interestingly, Table 5 suggests that more successful coaches chose forbearance more frequently. For example, forbearances accounted for $30 \%$ of all rationales for Coach 1 , who had won six championships (and five second places), and 37\% for Coach 9, who won four championships (and two second places). For comparison, all other coaches combined had only won two titles and their forbearance use averaged $17 \% .^{7}$

It may be that more accomplished competitors see the strategic value of forbearing, perhaps because they contemplate longer time horizons, broader contexts, and parties beyond the direct rival. It is possible too that accomplished competitors are more confident and better able to refrain from acting impulsively under pressure. Such discipline and composure manifested in forbearance may be critical to effective timing, resource orchestration, and misdirection (Andrevski \& Miller, 2020; Chen \& Miller, 2015).

Firms engaging in multimarket competition are especially likely to forbear strategically to achieve economic benefits (Gimeno \& Woo, 1996; Yu \& Cannella, 2013). Perhaps, as suggested above, such mindful engagement is especially likely to extend time horizons and the number of considered stakeholders and broaden strategic contexts; such careful reflection may yield superior returns. Multimarket competition research considers fear of retaliation across multiple markets as the primary reason for mutual forbearance. Our study suggests that multimarket rivals also might forbear to build resources for future attacks, optimize resource use, avoid conflicts with other stakeholders, or mislead rivals. We invite future researchers to assess these notions.

\section{Capability}

The capability to act and respond is also qualified by our findings. First, as noted, ignorance of primary rationales can thwart effective response, thus perhaps ultimately degrading the relevance of the stock of capabilities. Second, whereas the focus of prior studies has been 
on a rival's current stock of capital and knowledge resources (Chen, 1996; Connelly et al., 2017; Miller et al., 2019), our coaches paid more attention to dynamically managing their own team's capabilities rather than assessing those of rivals. Indeed, tactical actions often were intended to nurture, organize, and develop resources even in the throes of an intense competition. Thus, whereas AMC treats rivals' relative capabilities in a largely static manner, our findings suggest that capability can be a very dynamic aspect of rivalry that builds over time and considers interactions with multiple rivals both in the moment and in the future. Interestingly, whereas prior research focuses on capability to carry out actions, we find a reverse sequence; actions are initiated to develop capabilities. This finding enriches competitive dynamics research that has not "adequately embraced time-based actions that focus on building future competitiveness" (Chen, Michel, \& Lin, 2021: 15). Thus, tactics targeting longer term capabilities may play a subtle strategic role in competition.

In short, our research into rationales reveals a set of new opportunities for building and extending the AMC model in terms of neglected challenges to awareness, strategic aspects of motivation, and a more dynamic consideration of capabilities.

\section{Other Opportunities for Future Research}

Competitive dynamics scholars often view competitive behavior from a rational, game theoretic perspective (Chen \& MacMillan, 1992). However, as we have shown, the human element appears to be critical (see Kilduff, 2019; Kilduff et al., 2010). Our coaches attended to player morale and interaction, rival emotions, and the dignity of players and rivals. In inter-firm competition where reputation and firm image may matter greatly, similar considerations warrant further examination. Our coaches also considered multiple stakeholders of competitive engagement beyond direct rivals. In business, these would include customers, suppliers, and the public. Their roles in tactical competition remain to be explored (Chen \& Miller, 2015).

Action sequences constitute an uninterrupted series of competitive actions (Ferrier, 2001; Rindova, Ferrier, \& Wiltbank, 2010). Owing to rationale inscrutability, what rivals observe as a predictable sequence could instead be driven by diverse and unpredictable rationales. Moreover, coaches were careful to use the right players at the right times, to accelerate and slow down the pace of play as opportunities and threats evolved, and to attack and retreat when the time was right. This sequencing, pacing, or timing of behavior has been accorded less attention in the literature on competitive dynamics, and yet it is certain to figure very prominently in the behavior of businesses and the managers and entrepreneurs who run them.

In competitive dynamics, the role of deception appears to be a critical one and well worth further exploration (Sharapov \& MacAulay, 2020). Coaches initiated "fake" moves to confuse opponents or refrained from carrying out expected moves to conceal information or intent, set a trap, and surprise rivals. Indeed, previous work has examined the ethical and moral aspects of competitive bluffing (Guidice, Alder, \& Phelan, 2009), while microeconomists have studied the role of offensive feints in patenting decisions to mislead rivals (Hendricks \& McAfee, 2006; Langinier, 2005). Our study extends this domain by revealing a wide range of misleading actions and forbearances that can make competitive repertoires inscrutable to rivals. Further work in this domain may provide unique insights into the antecedents and consequences of providing intentionally misleading or incomplete information about competitive rationales (McGrath et al., 1998; Sharapov \& MacAulay, 2020). 


\section{Limitations}

Certainly, our study has limitations. Its context is specific: There is only one decisionmaker, the coach, and decisions take place in rapid sequence during a zero-sum game with clear rules. This is quite different from businesses where there are often multiple decision makers, with managers lower in the hierarchy making many tactical decisions, likely with fewer rules or temporal constraints than in basketball. In addition, although our coaches' rationales did sometimes consider the morale of an opposing team, it is unclear how much such contemplation figures in competition among firms. Finally, the games we studied took place early in the season. It is uncertain whether the longer term strategic orientation of tactical rationales would change later on as championships became closer.

Moreover, we selected a competitive context in which rivals rely exclusively on tactical actions. Although this enabled us to reveal strategic rationales for tactical actions, it limited our ability to examine links between tactics and other major strategic actions. Also, basketball coaches make quick decisions with limited action possibilities and timeframes, whereas business managers often have time to analyze data, generate alternatives, and execute actions. The less hectic pace may allow managers to be more strategic. Thus, as noted, we might expect an even richer set of rationales for tactical actions in a business context. Finally, it would have been nice to compare coaches and their repertoires for effectiveness, but this was limited by our small sample.

\section{Conclusion}

The field of competitive dynamics has been criticized as being undertheorized with too much emphasis on simple rational models and too little direct evidence of the complex human motivations underlying actual competition (Andrevski \& Miller, 2020; Chen \& Miller, 2012, 2015; Kilduff et al., 2010). Our investigation of tactical rationales reveals vibrant and multifaceted competitive rationales underlying observable rivalry. These rationales often reflect farsighted and subtle maneuvers, stratagems, and ploys driving tactical behavior. Clearly, studying observable tactics alone would reveal too little about the complex, sometimes ingenious, thinking behind them.

Our study broadens the foundations of competitive dynamics research, revealing that a single tactical action may be driven by a wide variety of competitive, organizational, and social rationales, many extending beyond a current exchange in time and parties implicated, and encompassing systemic and strategic considerations. Rationales revealed behavior that was purposefully deceptive, concealed, and deliberately withheld to surprise or mislead. Finally, rationale complexity and inscrutability could vary substantially across rivals, further giving rise to difficulties of interpretation and response, enhancing the competitive potential of tactical actions, and thereby importantly conditioning the classic AMC model to enhance the interpretability of tactical actions. In short, our findings suggest that the field can benefit from a more encompassing and nuanced portrayal of competitive interaction.

\section{ORCID iDs}

Goce Andrevski (iD) https://orcid.org/0000-0002-2196-5413

Isabelle Le Breton-Miller (iD) https://orcid.org/0000-0001-5755-2939 


\section{Notes}

1. Coaches' statements sometimes involved multiple rationales. The statistics above are based on the coders' first mentioned rationale for the statement. The index was much higher $(0.86)$ when we counted any match between the coders' rationales for each statement.

2. Eight rationales could be classified in another cell. For example, rationales such as "to surprise" or "to mislead" were mainly focused on tricking rivals for gaining short-term benefits. There were instances, however, in which the intended benefits had prolonged effects in the next quarters of the basketball game. Similarly, rationales in Cells III, VI, and IX primarily deal with external parties beyond current competitor, but they could also involve longer term strategic outcomes (e.g., to preserve rival dignity or to mislead future rivals).

3. A team includes coaches and players.

4. The identifiers AR (action rationale) and FR (forbearance rationale) correspond to the ID shown in Table 3, whereas the identifier CG (Coach \#, Game \#) in the text corresponds to the unique ID of a coach statement in our dataset not included in Table 3.

5. For example, coaches made a player substitution with a primary purpose to preserve rival dignity (AR 40; FR40), sanction a player (FR39), motivate a team (AR35; AR35), increase player confidence (AR36; FR36), create rival weakness or neutralize advantage (AR34; AR29), manage resource constraints (AR13; FR14; FR15), preserve and optimize resources (AR10; AR11), improve strategy execution (AR8), boost energy (AR6), or provide learning opportunities (AR3; FR3, AR4; FR4).

6. Whereas Coach 7 expressed 32.5 rationales per game, ranging from 23 to 42 , Coach 4 averaged a similar number of rationales per game, 30.75 , but with a much narrower range of 28 to 32 (see Table 5).

7. Although our study was not designed to confirm such findings statistically, out of curiosity we ran a mixed-effect logit model to tentatively assess whether these findings hold taking into account all observations and controlling for coach and team attributes (coach fixed effect, game effect, period of the game, time to interview, past game score, available players in the game, winning confidence, head coach experience). The results showed that coaches with more titles had $42 \%$ higher odds of forbearance (odds ratio $=1.42$, $p<0.02$ ), whereas head coach experience was unrelated to forbearance likelihood (these results are available on request).

\section{References}

Alvarez, M. 2010. Kinds of reasons. An essay in the philosophy of action. New York: Oxford University Press.

Andrevski, G., Brass, D., \& Ferrier, W. J. 2016. Alliance portfolio configurations and competitive action frequency. Journal of Management, 42: 811-837.

Andrevski, G., \& Ferrier, W. J. 2019. Does it pay to compete aggressively: Contingent roles of internal and external resources. Journal of Management, 45: 620-644.

Andrevski, G., \& Miller, D. 2020. Forbearance: Strategic nonresponse to competitive attacks. Academy of Management Review. DOI: 10.5465/amr.2018.0248.

Berman, S. L., Down, J., \& Hill, C. W. L. 2002. Tacit knowledge as a source of competitive advantage in the National Basketball Association. Academy of Management Journal, 45: 13-31.

Carnes, C. M., Xu, K., Sirmon, D. G., \& Karadag, R. 2019. How competitive action mediates the resource slackperformance relationship: A meta-analytic approach. Journal of Management Studies, 56: 57-90.

Chen, M. J. 1996. Competitor analysis and interfirm rivalry: Toward a theoretical integration. Academy of Management Review, 21: 100-134.

Chen, M. J., \& Hambrick, D. C. 1995. Speed, stealth, and selective attack: How small firms differ from large firms in competitive behavior. Academy of Management Journal, 38: 453-482.

Chen, M. J., \& MacMillan, I. C. 1992. Nonresponse and delayed response to competitive moves: The roles of competitors dependence and action irreversibility. Academy of Management Journal, 35: 539-570.

Chen, M. J., Michel, J. G., \& Lin, W. 2021. Worlds apart? Connecting competitive dynamics and the resource-based view of the firm. Journal of Management. DOI: 10.1177/01492063211000422.

Chen, M. J., \& Miller, D. 1994. Competitive attack, retaliation and performance: An expectancy-valence framework. Strategic Management Journal, 15: 85-102.

Chen, M. J., \& Miller, D. 2012. Competitive dynamics: Themes, trends, and a prospective research platform. Academy of Management Annals, 6: 135-210. 
Chen, M. J., \& Miller, D. 2015. Reconceptualizing competitive dynamics: A multidimensional framework. Strategic Management Journal, 36: 758-775.

Chen, M. J., Smith, K. G., \& Grimm, C. M. 1992. Action characteristics as predictors of competitive responses. Management Science, 38: 439-455.

Chen, M. J., Su, K. H., \& Tsai, W. 2007. Competitive tension: The awareness-motivation-capability perspective. Academy of Management Journal, 50: 101-118.

Chen, J., \& Nadkarni, S. 2017. It's about time! CEOs' temporal dispositions, temporal leadership, and corporate entrepreneurship. Administrative Science Quarterly, 62(1): 31-66.

Chi, L., Ravichandran, T., \& Andrevski, G. 2010. Information technology, network structure, and competitive action. Information Systems Research, 21: 543-570.

Connelly, B. L., Tihanyi, L., Ketchen, D. J., Carnes, C. M., \& Ferrier, W. J. 2017. Competitive repertoire complexity: Governance antecedents and performance outcomes. Strategic Management Journal, 38: 1151-1173.

Corley, K. G., \& Gioia, D. A. 2004. Identity ambiguity and change in the wake of a corporate spin-off. Administrative Science Quarterly, 49: 173-208.

Davidson, D. 1963. Actions, reasons, and causes. Journal of Philosophy, 60: 685-700.

Davis, W. A. 2013. The causal theory of action. In T. Connor \& C. Sandis (Eds.), A companion to the philosophy of action. West Sussex, UK: John Wiley \& Sons Ltd.

Day, D. V., Gordon, S., \& Fink, C. 2012. The sporting life: Exploring organizations through the lens of sport. Academy of Management Annals, 6: 397-433.

Eisenhardt, K. M. 1989. Building theories from case study research. Academy of Management Review, 14: 532-550.

Everson, S. 2013. Motivating reasons. In T. Connor \& C. Sandis (Eds.), A companion to the philosophy of action. West Sussex, UK: John Wiley \& Sons Ltd.

Ferrier, W. J. 2001. Navigating the competitive landscape: The drivers and consequences of competitive aggressiveness. Academy of Management Journal, 44: 858-877.

Ferrier, W. J., \& Lee, H. 2002. Strategic aggressiveness, variation, and surprise: How the sequential pattern of competitive rivalry influences stock market returns. Journal of Managerial Issues, 14(2): 162-180.

Ferrier, W. J., Smith, K. G., \& Grimm, C. M. 1999. The role of competitive action in market share erosion and industry dethronement: A study of industry leaders and challengers. Academy of Management Journal, 42: 372-388.

Gao, H., Yu, T., \& Cannella, A. A. 2016. The use of public language in strategy: A multidisciplinary review and research agenda. Journal of Management, 42: 21-54.

Gimeno, J., \& Woo, C. Y. 1996. Hypercompetition in a multimarket environment: The role of strategic similarity and multimarket contact in competitive de-escalation. Organization Science, 7(3): 322-341.

Gioia, D. A., Corley, K. G., \& Hamilton, A. L. 2013. Seeking qualitative rigor in inductive research: Notes on the Gioia methodology. Organizational Research Methods, 16: 15-31.

Gnyawali, D. R., \& Madhavan, R. 2001. Cooperative networks and competitive dynamics: A structural embeddedness perspective. Academy of Management Review, 26: 431-445.

Gomm, R., Hammersley, M., \& Foster, P. 2000. Case study and generalization. In R. Gomm, M. Hammersley, \& P. Foster (Eds.), Case study method: 98-115. London: Sage.

Grimm, C. M., \& Smith, K. G. 1997. Strategy as action: Industry rivalry and coordination. Reading, MA: Southwestern.

Grodal, S., Anteby, M., \& Holm, A. 2021. Achieving rigor in qualitative analysis: The role of active categorization in theory building. Academy of Management Review, 46: 591-612.

Guidice, R. M., Alder, G. S., \& Phelan, S. E. 2009. Competitive bluffing: An examination of a common practice and its relationship with performance. Journal of Business Ethics, 87: 535-553.

Guo, W., Yu, T., \& Gimeno, J. 2017. Language and competition: Communication vagueness, interpretation difficulties, and market entry. Academy of Management Journal, 60(6): 2073-2098.

Hambrick, D. C., Cho, T., \& Chen, J. M. 1996. The influence of top management team heterogeneity on firms' competitive moves. Administrative Science Quarterly, 41: 659-684.

Hendricks, K., \& McAfee, R. P. 2006. Feints. Journal of Economics \& Management Strategy, 15: 431-456.

Kilduff, G. J. 2019. Interfirm relational rivalry: Implications for competitive strategy. Academy of Management Review, 44: 775-799.

Kilduff, G. J., Elfenbein, H. A., \& Staw, B. M. 2010. The psychology of rivalry: A relationally dependent analysis of competition. Academy of Management Journal, 53: 943-969. 
Kilduff, G. J., Galinsky, A. D., Gallo, E., \& Reade, J. J. 2016. Whatever it takes to win: Rivalry increases unethical behavior. Academy of Management Journal, 59: 1508-1534.

Langinier, C. 2005. Using patents to mislead rivals. Canadian Journal of Economics/Revue canadienne d'economique, 38: 520-545.

Livengood, R. S., \& Reger, R. K. 2010. That's our turf! Identity domains and competitive dynamics. Academy of Management Journal, 35: 48-66.

Ma, H. 1999. Creation and preemption for competitive advantage. Management Decision, 37(3): 259-266.

MacMillan, I. C., McCaffery, M. L., \& van Wijk, G. 1985. Competitors' responses to easily imitated new products: Exploring commercial banking product introductions. Strategic Management Journal, 6: 75-86.

Marcel, J. J., Barr, P. S., \& Duhaime, I. M. 2010. The influence of executive cognition on competitive dynamics. Strategic Management Journal, 32: 115-138.

McGrath, R. G., Chen, M. J., \& MacMillan, I. C. 1998. Multimarket maneuvering in uncertain spheres of influence: Resource diversion strategies. Academy of Management Review, 23(4): 724-740.

Miller, D., \& Chen, M. J. 1994. Sources and consequences of competitive inertia: A study of the US airline industry. Administrative Science Quarterly, 39: 1-23.

Miller, D., \& Chen, M. J. 1996. The simplicity of competitive repertoires: An empirical analysis. Strategic Management Journal, 17: 419-439.

Miller, D., Pastoriza, D., \& Plante, J. F. 2019. Conditioning competitive risk: Competitors' rank proximity and relative ability. Journal of Economic Psychology, 73: 161-175.

Nadkarni, S., \& Barr, P. S. 2008. Environmental context, managerial cognition, and strategic action: An integrated view. Strategic Management Journal, 29(13): 1395-1427.

Nadkarni, S., \& Chen, J. 2014. Bridging yesterday, today, and tomorrow: CEO temporal focus, environmental dynamism, and rate of new product introduction. Academy of Management Journal, 57(6): 1810-1833.

Nadkarni, S., Chen, T., \& Chen, J. 2016. The clock is ticking! Executive temporal depth, industry velocity, and competitive aggressiveness. Strategic Management Journal, 37(6): 1132-1153.

Ndofor, H. A., Sirmon, D. G., \& He, X. 2011. Firm resources, competitive actions and performance: Investigating a mediated model with evidence from the in-vitro diagnostics industry. Strategic Management Journal, 32: 640-657.

O’Connor, T. 2013. Reasons and causes. In T. Connor \& C. Sandis (Eds.), A companion to the philosophy of action. West Sussex, UK: John Wiley \& Sons Ltd.

Perreault, W. D., \& Leigh, L. E. 1989. Reliability of nominal data based on qualitative judgments. Journal of Marketing Research, 26: 135-148.

Poppo, L., \& Weigelt, K. 2000. A test of the resource-based model using baseball free agents. Journal of Economics \& Management Strategy, 9: 585-614.

Porter, M. E. 2008. The five competitive forces that shape strategy. Harvard Business Review, 86(1): 25-40.

Rindova, V., Ferrier, W. J., \& Wiltbank, R. 2010. Value from gestalt: How sequences of competitive actions create advantage for firms in nascent markets. Strategic Management Journal, 31: 1474-1497.

Sharapov, D., \& MacAulay, S. 2020. Design as an isolating mechanism for capturing value from innovation: From cloaks and traps to sabotage. Academy of Management Review. DOI: 10.5465/amr.2018.0413.

Sirmon, D. G., Gove, S., \& Hitt, M. A. 2008. Resource management in dyadic competitive rivalry: The effects of resource bundling and deployment. Academy of Management Journal, 51: 919-935.

Smith, K. G., Grimm, C. M., Chen, M. J., \& Gannon, M. J. 1989. Predictors of response time to competitive strategic actions: Preliminary theory and evidence. Journal of Business Research, 18(3): 245-258.

Smith, K. G., Grimm, C. M., \& Gannon, M. J. 1992. Dynamics of competitive strategy. Newbury Park, CA: Sage Publications Inc.

Smith, K. G., Grimm, C. M., Gannon, M. J., \& Chen, M. J. 1991. Organizational information processing, competitive responses, and performance in the U.S. domestic airline industry. Academy of Management Journal, 34: 60-85.

Tavory, I., \& Timmermans, S. 2014. Abductive analysis: Theorizing qualitative research. Chicago: University of Chicago Press.

To, C., Kilduff, G. J., Ordonez, L., \& Schweitzer, M. E. 2018. Going for it on fourth down: Rivalry increases risk taking, physiological arousal, and promotion focus. Academy of Management Journal, 63: 1281-1306.

Tsai, W., Su, K.- H., \& Chen, M.- J. 2011. Seeing through the eyes of a rival: Competitor acumen based on rivalcentric perceptions. Academy of Management Journal, 54: 761-778. 
Van den Steen, E. 2018. The strategy in competitive interactions. Strategy Science, 3: 574-591.

Washington, M., \& Zajac, E. J. 2005. Status evolution and competition: Theory and evidence. Academy of Management Journal, 48(2): 282-296.

Withers, M. C., Ireland, R. D., Miller, D., Harrison, J. S., \& Boss, D. S. 2018. Competitive landscape shifts: The influence of strategic entrepreneurship on shifts in market commonality. Academy of Management Review, 43(3): 349-370.

Wolfe, R. A., Weick, K. E., Usher, J. M., Terborg, J. R., Poppo, L., Murrell, A. J., . . Jourdan, J. S. 2005. Sport and organizational studies. Journal of Management Inquiry, 14: 182-210.

Wright, P. M., Smart, D. L., \& McMahan, G. C. 1995. Matches between human resources and strategy among NCAA basketball teams. Academy of Management Journal, 38: 1052-1074.

Young, G., Smith, K. G., \& Grimm, C. M. 1996. “Austrian” and industrial organization perspectives on firm-level competitive activity and performance. Organization Science, 7: 243-254.

Yu, T., \& Cannella, A. A., Jr. 2013. A comprehensive review of multimarket competition research. Journal of Management, 39: 76-109. 